(d) a discharge of the jury, because of (erroneously) believed necessity, with no intent to relieve the defendant. ${ }^{107}$ The defendant's equities are strongest when he has secured a free and voluntary acquittal; if there are sufficient policy reasons to justify a new trial there, they must be sufficient to justify the retrial of a defendant whom no one acquitted or intended to acquit. ${ }^{108}$ The Supreme Court of Washington so reasoned, when, in a powerful opinion relying heavily on the Lee, Kepner, and Palko cases, ${ }^{109}$ it repudiated the general interpretation of constitutional "jeopardy" provisions that it had previously followed and sustained a statute giving the State the right to appeal from any order of a court except an acquittal. ${ }^{110}$

It would appear that this cannot be done in California by judicial decision. The meaning intended by the framers of the Constitution seems as well established as possible. The plea of "once in jeopardy" given by statute could scarcely be ignored, even were the Constitution re-interpreted. It has been shown, however, that it is within the power of the courts to make the jeopardy doctrine workable by keeping in mind its purpose, and by using a practical, common sense interpretation of the "legal necessity" exception.

\title{
INCOME TAX: DEDUCTIBILITY OF UNIFORM AND CLOTHING EXPENSES BY EMPLOYEES
}

Since its inception in 1913 the federal income tax law has consistently provided that, in computing net income, permissible deductions from gross income shall not include "personal, living, or family expenses." With equal consistency all income tax regulations promul-

107 The OFfictar DrafT apparently does not agree. It provides both (a) that the State may have a new trial, where a material error has been committed to its prejudice ( $\$ 13$ ), and (b) that a discharge of the jury, for any other cause than that "it is impossible to proceed with the trial, or to proceed without manifest injustice to the defendant or to the state" shall be a har to a new trial, unless "the defendant consents to or otherwise waives his right to object to such discharge" ( $\$ 7)$. Seemingly, these can only be reconciled with the view in the text on the assumption that material error prejudicial to the State can only be committed by, or at the request of, the defendant, and that such request is a "consent" or "waiver" to a second trial.

108 There are in fact weighty policy reasons (e.g., that of permitting a defendant to appeal to the mores of the commumity) for denying the State the right of appeal from an acquittal, and many, including the writer, beheve they outweigh the advantages of granting it. But, except in the case of a deliberate nolle prosequi filed by the prosecution, these policy reasons do not apply to the case of a discharge of a jury without a verdict. 109 Cited note 104 supra.

110 State v. Brunn (1945) 22 Wash. (2d) 120, 154 P. (2d) 826. See State v. Thierfelder (1943) 114 Mont. 104, 111, 132 P. (2d) 1035, 1038.

1 INT. REv. CODE $\S 24(\mathrm{a})(1)$; Revenue Acts of 1938, 1936, 1934, 1932, 1928, § 24 (a) (1); Revenue Acts of 1926, 1924, 1921, 1918, § 215(a); Revenue Act of 1916-17, \& 5; Revenue Act of 1913, \& 2(B). INT. REv. CODE \$ 24(d) (1), however, now expressly excepts from this disallowed category "extraordinary medical expenses deductible under section $23(x)$." 
gated since the Revenue Act of 1918 have included the following statement as partially interpretive of this provision of the law: "The cost of equipment of an Army officer to the extent only that it is especially required by his profession and does not merely take the place of articles required in civilian life is deductible. Accordingly, the cost of a sword is an allowable deduction, but the cost of a uniform is not."2 On the positive side of the law, where allowable deductions from gross income are specified, it has been provided, since 1918, that "ordinary and necessary expenses paid or incurred during the taxable year in carrying on any trade or business" are deductible. ${ }^{3}$ In addition to this, Congress im 1942 broadened the scope of allowable deductions to include non-trade or non-business expenses where paid or incurred "for the production or collection of incoine, or for the management, conservation, or inaintenance of property held for the production of incoine." 4

It becomes apparent at once that neither the above cited statutory provisions nor the Treasury Regulations pertaining thereto ${ }^{5}$ deal specifically with the problem of when, if ever, the cost of purchase and cleaning of civilian uniforms and work clothing constitutes a deductible expense to the wearer.

\section{Treatment by the Bureau of Internal Revenue}

From 1918 until 1938 the Bureau of Internal Revenue categorically demed any deduction for the cost and maintenance of uniforms and work clothing on the ground that such were personal expenses in that they replaced regular clothing. The first general ruling which indicated the Bureau rationale concerning civilian uniforms was embodied in I.T. $1488,{ }^{6}$ which stated: "Uniforms of nurses, railway traininen, barbers, surgeons, and baseball players are held to take the place of ordinary clothing and the amounts expended by the wearer for the purchase of such uniforms are therefore held to be personal expenses, the deduction of which is specifically denied by $\$ 215$ (a) (1)

2 U.S. Treas. Reg. 111, § 29.24-1 (1943) ; U.S. Treas. Reg. 103, § 19.24-1 (1940); U.S. Treas. Regs. 101 (1938), 94 (1936), 86 (1934), art. 24-1; U.S. Treas. Regs. 77 (1932), 74 (1928), art. 281 ; U. S. Treas. Regs. 69 (1926), 65 (1924), 62 (1922), 45 (1920), art. 291.

3 INT. Rev. Code $\$ 23$ (a) (1) (A) ; Revenue Act of 1938, $\$ 23$ (a) (1) ; Revenue Acts of 1936, 1934, 1932, 1928, $\S 23$ (a) ; Revenue Acts of 1926, 1924, 1921, 1918, $\$ 214$ (a)(1). Section 2(B) of the Revenue Act of 1913 failed to include the words "ordinary" and "trade," but was otherwise substantially the same. Section 5 of the Revenue Act of 1916 did not include the word "ordinary."

4 (1942) 56 Star. 798, 819, 26 U.S. C. $\$ 23$ (Supp. 1946). See Comment (1946) 34 CALIF. L. Rev. 212.

5 See note 2 supra; U.S. Treas. Reg. 111, $\$ 29.23$ (a)-1 to (a)-16 (1943).

${ }^{6}$ I-2 Conr. Burr. 145 (1922). A similar ruling was issued as to deductions by professional golf players by G. C. M. 7133, VIII-2 CuM. ButL. 85 (1929), which held that the purchase and laundering of articles of wearing apparel of professional golfers constitute a personal expense. 
of the Revenue Act of 1921." T This ruling followed on the heels of a publication $^{8}$ which dealt with a somewhat difficult question involving naval uniforms and which applied the same reasoning as I.T. 1488. The situation there presented involved regulations issued by the Navy Department requiring that all officers purchase each of nine different uniforms. The taxpayer argued that since the regulations specified in minute detail the particular style of uniforn and equipment to be worn on each individual occasion, such unifornis could not be said to take the place of civilian clothes, and that they should be classified as business assets for which a depreciation deduction should be allowed. It was stated, however, that the uniforms were "clothing" and that although the occasions on which they were to be worn were specified, the regulations did not prohibit their wear at events of a non-official character; hence, when the unifornis were worn on the latter occasions, they took the place of civilian dress and must necessarily be considered a personal or living expense.

The correlative situation to that dealt with above was tested and decided in $1924 .{ }^{\circ}$ An order of the Secretary of the Navy had specified that civilian clothing would be worn at certain times by all officers and others on duty with the Navy Department. As a result of this, it was contended, the uniforns no longer "replaced" civilian clothing since an officer must purchase and maintain both. It was held that the uniform expenses were still personal despite the Secretary's order. The ruling pointed out that the uniforms, when worn at the times and on the occasions specified by the regulations, took the place of civilian dress. ${ }^{10}$ The same year, however, in keeping with the Treasury Regu-

7 Prior to I. T. 1488 two specific rulings had been issued disallowing civilian uniform deductions and one disallowing a naval uniform deduction (infra note 9). 0.D. 951, 4 CoM. BuxL. 209 (1921) held that expenses incurred by a railroad conductor in the purchase of uniforms which his employer required him to wear during business hours were personal and not deductible. I. T. 1419, I-2 CuM. Bux. 145 (1922) disallowed a deduction to a professional masseuse, who was required to wear a special uniform and to change the same after each treatment, on the ground that the cost and laundering of the uniforms were personal expenses.

8 A. R. R. 594, 5 CUM. BULL. 154 (1921).

9 I. T. 1937, III-1 CUM. BurL. 200 (1924).

10 Early Bureau rulings went even further in disallowing the cost of uniforms as deductions. In I. T. 1965, III-1 CUMr. BuxL. 201 (1924), it was held that items of equipment such as gold lace, chin strap, gilt buttons, gilt and silver devices on the caps, and gold lace and gilt buttons on the uniforms are considered a part of the umiform and cap which take the place of regular clothing, and the cost thereof may not be deducted. It was also held that the cost of altering the equipment on a uniform subsequent to promotion or demotion was a personal expense and not deductible. 20 years later I. T. 1965 was modified by I. T. 3694, 1944 CuM. BurL. 92, to the extent that the cost of gold lace, cap devices, and insignia of rank were held to constitute a deductible business expense, on the ground that I. T. 1965, insofar as it disallowed such deductions, was imconsistent with § 29.24-1 of U.S. Treas. Reg. 111, supra note 2. The Bureau pointed out that these items cannot be deemed to take the place of any part of the clothing ordinarily worn by a civilian since they serve a functional, rather than decorative, purpose which is specially required by the profession. 
lations, ${ }^{11}$ it was held that the cost of items of equipment such as corps devices, Sam Browne belts, epaulets, campaign bars, and aiguillets were deductible as business expenses. ${ }^{12}$

Relaxation of Bureau policy with reference to actual wearing apparel first occurred in 1938 when the question of a deduction for the cost and cleaning of a jockey's uniform arose. In a General Counsel's Memorandum ${ }^{13}$ it was held that since the articles of riding apparel (trousers, jockey shirts, riding boots, and caps) were (1) especially required by the jockey's business, (2) used solely in such business, and (3) did not appear to be adaptable to general or continued wear to the extent that they might be said to replace the jockey's regular clothing, the expenditures were properly deductible as business expenses under section 23 (a) of the Revenue Act of $1936 .{ }^{14}$ In order to harmonize the Bureau's position with this ruling it was necessary to revoke so much of I.T. 1488 as held that expenditures of professional baseball players for the purchase of uniforms used solely in the wearer's business are personal and non-deductible..$^{15}$

Another inroad on the Bureau's early policy of absolute disallowance occurred in regard to special clothing or equipment worn for safety purposes. In 1940 the Bureau ruled that helmets, rubber coats, and rubber boots purchased and worn by firemen and policemen were allowable deductions, ${ }^{16}$ employing the same test that the articles must be specially required in the taxpayer's business, used solely in that business, and not adaptable to general or continued wear to the extent that they may be said to replace regular clothing. ${ }^{17}$

It will be noted that the evolution of the Bureau's policy has not resulted in a reversal of doctrine. From the beginning it has been held that occupational clothing which replaces regular clothing is a personal expense; the liberalization has developed simply through a more analytical test of what constitutes replacement. With the refinements have ultimately come a series of litigated cases creating an unsettled condition of the law.

11 See note 2 supra.

12I. T. 1965, III-1 CUM. BULL. 201 (1924).

13 G. C. M. 19662, 1938-1 Com. BuL.. 118.

14 See note 3 supra.

15I. T. 3176, 1938-1 CuMr. BuLd. 348. This partial revocation followed a recommendation to that effect in G. C. M. 19790, 1938-1 CoMr. BuLr. 118, where it was stated that in the opinion of the General Counsel baseball uniforms are analagous to theatrical costumes purchased exclusively for use in the production of a play and unsuited to wear outside of working hours, and hence are not adaptable to general or continued wear to the extent that they may be said to replace regular clothing.

18 I. T. 3373, 1940-1 CuMr. BuLx. 28.

17 See note 13 supra. 


\section{Treatment by the Courts}

For twenty-five years there was virtually no litigation challenging the Bureau's position on disallowance of clothing deductions, ${ }^{18}$ except in situations involving expenditures for theatrical costumes. ${ }^{10}$ In the latter cases there was no discussion by the Board of Tax Appeals as to replacement of regular clothing; rather, allowance of the deductions was placed on the ground that since the items were required by the actor in his profession and were used solely therein, they were to be considered as an ordinary and necessary business expense. In 1943, however, four cases decided by the Tax Court completely upset the hitherto established policy of the Bureau. Beginning with Marcus $O$. Benson, which was affirmed by the circuit court of appeals, ${ }^{20}$ the court overruled the Commissioner and held deductible the expenses of a California Highway Patrolman for the cost and cleaning of his uniforms. In that case the petitioner was required to furnish and maintain his own uniform, including shirts and ties, which had to conform strictly to specifications. In reaching its conclusion the court pointed out that (1) the uniform was used ordinarily only while petitioner was on duty, (2) the cost of the uniforn was at least twice as great as the cost of an' ordinary suit of civilian clothes and the cleaning expenses were especially large, and (3) the uniform was subject to severe wear and tear. In view of this the court felt that there could be no reason for treating these expenses differently than those relating to the cost of petitioner's revolver and handcuffs, for which the Commissioner had allowed deductions.

In one sense it can be argued that this decision did not repudiate the early administrative test of "replacing regular clothing" since it stressed the fact that the uniform ordinarily was worn only while on duty; however, such reasoning seems more academic than practical. The fact remains that the patrolman's uniform "replaces" his regular clothing during the entire working week, much the same as in the case

${ }^{18}$ In one case, George E. Hall (1928) 10 B.T. A. 847, the Commissioner's decision was appealed to the Board of Tax Appeals. Deceased had deducted $\$ 50$ for the taxable year 1923 to cover expenditures for gold lace used on his naval unform. The Board upheld the Commissioner's disallowance of the deduction on the ground that it was a personal expense.

10 Charles Hutchison (1928) 13 B.T. A. 1187 (Acq.) (allowing deduction for clothing expense of a stunt man whose clothes became a total loss at the end of a picture); Regimald Denny (1935) 33 B.T.A. 738 ( $A c q$.$) (allowing actor's deduction for all cos-$ tumes, wigs, and make-up which he was required to purchase); Helen Menken (1939) B.T.A. Memo. Op., Dkt. 94263 (allowing actress' deduction for costumes, wigs, shoes, and other articles necessary in her profession which she was required to purchase).

20 (June 1, 1943) 2 T. C. 12 (Nonacq.), aff'd, (C. C. A. 9th 1944) 146 F. (2d) 191. Alexander F. Vahrenkamp (June 2, 1943) T.C. Memo. Op., Dkt. 111588, petition for review dismissed, (C. C. A. 9th 1945) 146 F. (2d) 1001, a companion case involving the same facts and decided the following day, held the expenditure deductible as an ordinary and necessary expense of earning a livelihood, citing Benson. 
of an Army officer, and his off-duty change into ordinary clothes was not required but rather prompted by his own comfort and convenience. It is in no sense analagous to the situation of a baseball player or jockey whose umiforms are not adaptable to any street wear and are worn only during brief performances. Realistically, the Benson case should be considered as a complete repudiation of the liberalized Bureau position since it allowed a deduction for what can be considered a full time uniform. Consideration must be given to subsequent decisions to determine, if possible, what the new Tax Court test comprises.

In Eleanor E. Meier ${ }^{21}$ and Helen $K$. Harsaghy ${ }^{22}$ the question of deduction for nurses' umiforms, theretofore flatly disallowed by the Bureau, ${ }^{23}$ was considered. In the Meier case the difficulties of overruling prior policy and allowing the deduction were made easy for the Tax Court in view of the extenuating circumstances present. The taxpayer was employed in a tuberculosis hospital and because of the communicable nature of the disease afflicting her patients could not wear her uniform at any time other than during actual duty hours at the hospital. In the Harsaghy case, however, decided just nine days later, allowance of the deduction was based on less compelling facts, and the decision is a clear-cut precedent for deductibility of all nurses' uniform expenses. The taxpayer was a private duty nurse attending a single patient each night during 1940. In allowing her a deduction for the cost and laundering of her uniforms, the Tax Court purported to follow the Bureau test and held that such clothing was not adaptable to general and continued wear to the extent that it replaced regular clothing. The court rationalized its position by stating that although the uniform may suffice as "wearing apparel," it does not necessarily follow that it replaces regular clothing; the test of replacement should be based on what the taxpayer's contemporaries outside the profession customarily wear, with regard to style, color, and material. A supporting factor was the fact that custom and ethics of the profession, as well as observance of aseptic principles, virtually prevented the taxpayer from wearing the uniform except when actually attending her patient, even when going to and from her place of work.

The Tax Court has continued to indicate that at least it will be consistent in allowing deductions for uniform expenses of civilians, despite inconsistencies which result when viewed in connection with Bureau policy. In the case of a railroad passenger conductor, ${ }^{24}$ who

21 (July 21, 1943) 2 T. C. 458 (Nonacq.), Commissioner's appll dismissed (C. C. A. 3d 1945) (Acq.).

22 (July 30, 1943) 2 T. C. 484 (Nonacq.), Commissioner's app'l dismissed pursuant to stipulation (C. C. A. 2d 1945) (Acq.).

23 I. T. 1488, I-2 CuM. BuLl. 145 (1922).

24 Charles Wildman (1946) T. C. Memo. Op., Dkt. 10061. 
was required to purchase and maintain a special uniform, the court allowed the deduction on the same grounds set forth in the Harsaghy opinion, stressing the fact that the specially cut and equipped uniform was greatly dissimilar to ordinary clothes and that it was worn in fact only while on duty. The most extreme situation in which a uniform deduction was allowed occurred in Bennie Blatt, ${ }^{25}$ which involved a milkman and wholesale bakery salesman. In that case the baking company had placed no restrictions on the wearing of the uniform except that it always be worn at work and not worn in any place which would bring reproach on the wearer or the company. As a result, the taxpayer wore his uniform to and from work and in public eating places for breakfast and lunch, although he did not wear it socially or around his home. The court conceded that the uniforn was comfortable to wear and nade of desirable material and that if the taxpayer left his job he could remove the company coat label and use the articles as regular clothing. Nevertheless, said the court, he did not quit his job and basically he wore the uniform only in the course of his employment, which factors rendered it inadaptable to general or continued wear.

The most recent decision in point is Harry $R$. Leacock, ${ }^{20}$ which fails to help formulate any clear-cut test as to deductibility. The taxpayer, a civilian employee of Douglas Aircraft, was sent to an African air base operated under army supervision. At times it was necessary that he enter combat areas and on such occasions he was required to wear, at his own expense, the uniform of a United States Army officer. The court held simply that the cost of the uniform, less salvage value, was deductible, citing Benson, Meier, and Harsaghy and omitted any detailed discussion of the reasons therefore.

A survey of the foregoing cases reveals that the Tax Court has adhered to the Bureau test that before an item of apparel can be deductible it inust be specially required by the taxpayer's business. Further, it has rendered at least lip service to the requirements that the item be used solely in the business and be not adaptable to general or continued wear, although the connotations given the latter are at variance with the Bureau interpretation. However, as to the proposition that the apparel must not replace regular clothing, it is impossible to conclude that the Tax Court has not effected a repudiation. At this point a generalization may be attempted: (1) if special work clothes are required and are civilian uniforms of the conventional type-that is, worn solely on the job and not suitable for off-duty wear-a deduction will be allowed; (2) if special work clothes are required and are civilian uniforms which, although not worn exclusively on the job,

25 (1947) T. C. Memo. Op., Dkt. 10064.

26 (Dec. 19, 1947) T.C. Memo. Op., Dkt. 7730. 
are not such as are ordinarily worn at home or on the street, a deduction will probably be allowed, in view of the Blatt decision.

It is not clear how much importance, if any, is ascribed to the fact that the expense occasioned by the uniform exceeds that connected with the purchase and maintenance of ordinary clothes. The point is discussed in the Benson, Vahrenkamp, ${ }^{27}$ and Blatt cases; in the others it is not, although there is generally some reference to the necessity for frequent laundering or severe wear and tear. It is therefore somewhat speculative as to what the result would be if the same facts were present as in the Benson case except that the cost of purchase and maintenance of the uniform did not exceed that of ordinary clothes. Perhaps the most important question to be answered is the extent to which the Wildman and Blatt decisions ${ }^{28}$ will control deductions for other types of uniforms, such as those of filling station attendants, waitresses, elevator operators, and the like. It is submitted that im the ahsence of statutory changes they will be followed without question.

It is noteworthy that for the most part the decisions rendered in the uniform cases have not carried over to work clothes which are not sufficiently "special" to fall within the classification of uniforms. The rationale is apparently that such work clothes are not specially required by the employer. Out of four such cases litigated only one has been successful in obtaining a deduction. In this latter case ${ }^{29}$ petitioners incurred expenses for the daily cleaning of work clothes worn while on duty at a roller bearing plant and not worn elsewhere. The clothes could be worn only one day at a time since they habitually became saturated with oil, which caused them to sag and created a danger of their being caught in plant machinery. The decision permitted a deduction as an expense resulting from the hazards of the business; a footnote by the court stated that the expenditures were clearly within I.T. 3373 (safety equipment, including helmets, rubber coats, and rubber boots for firemen and policemen) ${ }^{30}$

The three decisions which disallowed the deductions on the ground that they were personal expenses (Louis Drill, ${ }^{31}$ Alma Thurman, ${ }^{32}$ Carrie E.L.Mullins ${ }^{33}$ ) were careful to distinguish the Benson, Meier, and Harsaghy cases by pointing out that in the latter situations petitioners were required by their employers to wear a particular uniform, whereas at bar the taxpayers bought the special work clothing volun-

2T Alexander F. Vahrenkamp (1943) T. C. Memo. Op., Dkt. 111588.

28 Notes 24 and 25 supra.

29 Elwood J. Clark (1946) T. C. Memo. Op., Dkts. 9059, 9135, 9167, a'ffd, Clark v. Commissioner of Int. Rev. (C. C. A. 6th 1946) 158 F. (2d) 851.

30 1940-1 Cuns. Bure. 28.

31 (1947) 8 T. C. 902.

32 (1947) T. C. Memo. Op., Dkt. 10185.

33 (1947) T. C. Memo. Op., Dkt. 10353. 
tarily for their own convenience. In the Drill case petitioner, an outside superintendent for a building contractor, admittedly subjected his clothing to certain occupational hazards and severe wear and tear, but the court felt that these circumstances did not justify a deduction. It was stressed that the clothing petitioner wore at work was the same type as that worn generally, and the fact that it became torn and soiled by the end of a day to the extent that he would not want to wear it for social purposes was immaterial. In the Thurman and Mullins cases, both of which dealt with attempted deductions by women employed in a textile mill, the facts were stronger for disallowing the deductions. Concededly, petitioners had purchased dresses for work of a quality inferior to that of their regular clothing in order to conserve the latter. The court stated that to allow a deduction in such a case would necessitate the allowance of a proportionate part of all clothing and laundering expenses borne by all workers. The logic of this argument is hard to question; however, when it is viewed in connection with the uniform cases, is there a sufficiently sensible distinction between special clothing required by the employer and special clothing of about the same price purchased voluntarily by the employee to justify a deduction in the first case and a disallowance in the second? Moreover, what would be the situation if the employer specifically required a laborer to wear overalls, admittedly less expensive than street clothes, but hardly classifiable as a uniform?

It should be noted that the Bureau position is still being maintained with regard to non-deductibility of military uniform expenses, since the Tax Court has held that articles of military apparel, other than what can be termed "special equipment," are adaptable to general wear and therefore are not deductible under the Benson and succeeding cases. ${ }^{34}$

\section{Classification of Clothing Expenses}

Before a solution can be proposed, the paranount question is whether, under existing statutory provisions, all, part, or none of the expenses incurred in the purchase and naintenance of occupational clothing is properly classifiable as a deduction under section 23(a). It has been established that the allowance of deductions is sanctioned only where there is clear legislative provision for the particular deduction claimed. ${ }^{35}$ Proponents of the early Bureau position might maintain that since section 23 (a)(1) provides specifically for such deductions as travel expenses, Congress must have intended to ex-

34 W. W. Bercaw (1947) T. C. Memo. Op., Dkt. 7263, aff'd (C. C. A. 4th 1948) $165 \mathrm{~F}$. (2d) 521.

35 Deputy v. Du Pont (1940) 308 U.S. 488; White v. United States (1938) 305 U.S. 281; New Colonial Co. v. Helvering (1934) 292 U.S. 435; 4 MERTENs, Lnw of FEDERAL INCOME TAXATION (1942) § 25.03. 
clude clothing costs by failing to mention them. This is at best a weak argument, since section 23 (a) (1) purports to allow all business expenses. If clothing expenses are busmess expenses in certain instances, it seems logical that they must be included, and the fact that travel expenses are specifically mentioned and clothing expenses are not would seem to be irrelevant. Thus, this easy solution is clearly untenable, and we are faced with the question of what constitutes a business expense, under section 23(a)(1), or a non-business expense paid or incurred for the production or collection of income, under section 23(a) (2). It inay be significant that the important Tax Court decisions allowing the deduction have all occurred since 1942, the year in which the scope of section 23(a) was broadened to include the specified non-business expenses. Possibly this is because there was a tendency before the enactment of section 23(a) (2) to characterize all non-business expenses as personal, ${ }^{36}$ and perhaps it was thought that the clothing of an employee, although purchased in order to produce income, could not be called a business expense. Unfortunately, the cases do not indicate how much reliance was placed on this new legislation. For example, in the Benson case the Tax Court seems to treat the deduction as a business expense, whereas the affirming opinion of the circuit court of appeals classifies it as one incurred and paid for the production of incoine; the Harsaghy case is based on a business expense; the Wildman decision stresses both grounds in the Tax Court opinion alone; and the Blatt and Leacock cases fail to specify either.

Whether the expenses be business or non-busmess, in order to be deductible they inust be both "ordinary and necessary." In Welch $v$. Helvering ${ }^{37}$ the Supreme Court discussed the meaning of "ordinary," stating that it need not be habitual, and in Blackmer v. Commissioner $^{38}$ it was said that "necessary" means simply "appropriate and helpful." These defintions are liberal; hence the problenn of "ordinary and necessary" may be easily hurdled. But the taxpayer is still confronted with the question of whether or not the expenditure is "personal" within the interdiction of section 24(a) (1). To illustrate, in Sparkman v. Commissioner ${ }^{39}$ petitioner, an actor, claimed a deduction for a set of false teeth. The court held that no deduction was allowable because there was no showing that the teeth were used or intended for business purposes only; however, a dictum states that although the purchase inay have occurred in connection with petitioner's profession, the expenditure was so purely personal in char-

${ }^{86}$ Brodsky and McKibbin, Deduction of Non-Trade or Non-Business Expenses (1946) 2 TAX L. Rev. 39.

37 (1933) 290 U.S. 111.

38 (C. C. A. 2d 1934) 70 F. (2d) 255.

39 (C. C. A. 9th 1940) 112 F. (2d) 774, 777. 
acter as to deny it classification as a business expense. Although it is not of much help, the conceptualistic distinction has been made that ordinarily an item falls within the business expense classification if incurred in producing revenues in the business as distinguished from expenses incurred for the convenience, coinfort, or economy of the individual in pursuing his business. ${ }^{40}$

\section{Problems Created by Present Rules}

It is clear that the incomplete series of rules that has been handed down to date will create vexing problems. The following seem most apparent:

(1) Where a distinction is drawn between civilian uniforms and special work clothes, and even within the latter classification exceptions are made here and there, administrative difficulties arise as to where to draw the line between personal and business expenses.

(2) The Bureau has resisted the liberalizing policy of the Tax Court, as a result of which the Commissioner may recognize a deduction only in the precise fact situations already litigated. This means first, that considerably more litigation is inevitable, and second, that an anomalous result is likely, depending on whether or not a taxpayer consults his collector regarding uniform deductions. Presumably, if he makes out his own return and claims the deduction, he will eventually be upheld by the Tax Court; whereas, if he consults the collector, he will not even claim the deduction (on the advice of the collector) unless it falls within a specific situation already litigated.

(3) There is a possibility that if the Tax Court maintains its liberalizing policy, without Congressional adjustment, uniform expenses will increase many wage earners' deductions to a point beyond the standard deduction of ten per cent. ${ }^{41}$ This would force the taxpayer to itemize his deductions on the long return (long form 1040) in order to claim the full amount, and thereby preclude him from using the simplified final return (form W-2 withholding receipts) (2) $^{42}$ or the simplified tax table provided in Supplement $T$ of the Code. ${ }^{43}$ This would create inconvenience and difficulty for the taxpayer and additional administrative work for the Government.

Another aspect of this problem involves the concept of adjusted gross income, applicable when the optional standard deduction is utilized. The Tax Court rulings on umform deductions may well foster discrimination between classes of taxpayers electing the standard deduction. If the taxpayer is an employee performing services, he is not

104 Mertens, Law of Federal Inconse Taxation (1942) $\$ 25.04$ and cases cited.

41. IVT. REv. CODE § $23(\mathrm{aa})$.

42 INT. REv. CODE $\$ 51(f)$.

13 INT. Rev. CODE $\$ 400$. 
entitled, in arriving at adjusted gross income, ${ }^{44}$ to deduct any expenses attributable to his trade or business except those paid or incurred under some sort of reimbursement arrangement with his employer ${ }^{45}$ This means that if the wage earner avails himself of the standard deduction, he will get no added benefit from the clothing deductions; in order to derive any benefit he will have to itemize all his deductions on the long form return. On the other hand, in the case of a professional man, e.g., a doctor, no such limitation applies, ${ }^{46}$ and this taxpayer could deduct the cost of his surgical and other uniforms in arriving at adjusted gross income and then avail himself of the standard deduction.

(4) Finally, there is the perennial possibility of an adverse effect on revenues beyond the contemplation of Congress.

\section{Possible Changes}

The need for Congressional clarification in the employee clothing deduction field is one proposition that can be asserted unequivocally at this time. There are three broad legislative possibilities:

(1) Congress could specifically permit a deduction for the cost and maintenance of all clothing used in one's occupation. This is a simple approach which obviates the problem of distinguishing between an elevator operator who is required to wear a uniform and a bank teller or floor walker who must wear a clean shirt every day and purchase several suits of reasonably high quality. It is open to the obvious objection that it is impossible to determine equitably, as a blanket proposition, how much should be allowed as a maximum. Furthermore, this solution might well open the door to deductions for other "business-personal" expenses such as meals, commuting, and educational expenses. Finally, it would be exceedingly difficult to ascertain when deductions had been padded.

(2) Congress could specify deductions for clothing in certain instances and deny them in others. It might be necessary under this solution either to increase the ten per cent standard deduction or allow such expenses to be recognized in computing adjusted gross income, so as to avoid forcing employees off the sinplified short forn return. It is open to the objections discussed supra, notably illogical and mequitable distinctions and administrative difficulties in corroborating the accuracy of deductions. If this course of action were adopted, the first possibility which suggests itself is the allowance of deductions in accordance with Tax Court criteria set forth in the cases already decided. It has already been pointed out that this is a highly unsatisfac-

44 INT. Rev. CODE § 22(n)(1).

45 INT. Rev. CODE $\$ 22$ (n) (3).

46 See note 44 supra. 
tory solution since such criteria are neither precise nor are they based on disproportionately high costs. Seemingly, the better approach would be the recognition of the principle that in certain extreme cases occupational clothing expenses are disproportionately high and should rightfully be considered a direct incident of the trade or business. Under this test, the following suggest themselves as possible standards:

(a) Deductions could be permitted only insofar as the cost of special work clothes exceeds that of ordinary clothes in the individual case.

(b) An allowance for special work clothes could be permitted to the extent that the expense incident thereto exceeds a certain percentage of the income derived from the trade or business for which such clothes were acquired.

(c) Deductions could be permitted by those engaged in occupations in which expenditures for clothes are found to be increased disproportionately because of the nature of their occupations.

(3) Congress could specify that all clothing expenses are personal and non-deductible. This solution bears the same recommendation as the first possibility discussed, viz., the elimination of problematical distinctions between "special" and "ordinary" work clothes. Its most vulnerable point is the possible inequity resulting where clothing expenses are disproportionately high and directly attributable to the nature of the taxpayer's occupation. Also, it is quite likely the courts would construe such special items as safety apparel, and theatrical costumes to be other than wearing apparel, and hence deductible, thereby opening the door to the same old exceptions. It is submitted that these objections are far outweighed by the desirability of such a policy. Clothing is inherently a personal expense, at least as much so as food, commuting, and educational expenses. Amounts spent on occupational clothing do not appear to have reached such serious proportions as to require the special legislative dispensation found necessary in the case of extraordinary medical expenses.

In line with the obvious need for Congressional clarification, the Treasury Department early this year proposed ${ }^{47}$ that the following specific legislation covering deductions for occupational work clothes be enacted: "It is recommended that the long-established administrative practice of the Bureau of Internal Revenue, with respect to the allowance of deductions for the cost of work clothes, be confirmed by specific legislation disallowing such deductions except as to work clothes which are especially adapted to a particular occupation, and which do not substitute for, or relieve the taxpayer from providing himself with, ordinary working or wearing apparel." At best, this ap-

475 C. C. H. FED. TAX REP. If 6090 (1948). 